\title{
PHARMACEUTICAL INDUSTRY DEVELOPMENT: KEY POLICY INSTRUMENTS IN CHINA
}

\author{
Daria Honcharenko \\ Directorate of Industrial Policy and Stimulation of Regions' Development \\ Ministry for Development of Economy, Trade and Agriculture of Ukraine \\ 12/2 M. Hrushevskoho str., Kyiv, Ukraina, 01008 \\ dp170292ddo@gmail.com
}

\begin{abstract}
The article provides an overview of programs, plans, tools of scientific and technological, innovation and industrial policy aimed at creating and producing new drugs in China; it is substantiated that the Chinese government uses an integrated approach in the implementation of mechanisms to protect and strengthen the pharmaceutical industry. It is demonstrated that the Chinese government provides business support in the form of subsidies, tax incentives, the creation of special zones for the development of high-tech industries, and helps to attract foreign direct investment in contract manufacturing and research and development, accompanied by technology transfer; through the public procurement system, a program for the development of endogenous innovations is implemented through the provision of price preferences, and advanced foreign technologies are involved. State support contributed to an increase in the level of localization of production and an increase in the number of jobs, an increase in the added value of production and the competitiveness of the pharmaceutical industry, the formation of scientific and technical competencies and the development of technologies, the creation of objects of intellectual property rights. The Chinese model of investment and innovative development, relying on the use of external technological, production, human resources, has made it possible to form a high-tech pharmaceutical sector capable of producing endogenous innovations. Given the objectives of the policy documents, Chinese enterprises are encouraged to invest in other countries in the interests of the development of Chinese pharmaceuticals.
\end{abstract}

Keywords: pharmaceutical industry, technology, innovation, government aid, tax incentives, subsidies, public procurement, industrial policy.

DOI: $10.21303 / 2504-5571.2020 .001369$

\section{Introduction}

According to the updated forecast of the International Monetary Fund, the fall of the global economy in 2020 as a result of the COVID-19 pandemic may be $4.9 \%$ [1], will have significant negative socio-economic consequences for all countries, worse than from the global financial crisis of 2008. Leaders of European countries-world leaders are looking for ways to help businesses that are suffering from the problems caused by the outbreak of the epidemic, relying traditionally on horizontal support measures [2]. At the same time, China has focused on the restored stable operation of leading industries, which are the "pillars" of the national economy. One of them is pharmaceuticals. According to the US National Science Foundation Report - 2020 [3], in terms of value added, China's drug production already ranks third in the world - 162,527 million USD, the value of the USA indicator - 181,800 million USD, EU - 183,542 million USD.

Experts who have studied the phenomenon of exponential development of China's pharmaceuticals state that the intervention of the Chinese government at the infrastructural and political levels and concrete actions for state aid contributed to the creation of a prosperous industry [4]. Numerous works confirm this thesis. The authors of the study of obstacles and opportunities for innovation in the pharmaceutical industry [5] point out that the key barriers in China in the development of new drugs are academic, industrial, institutional and financial constraints, therefore structural transformations and a change in reputation from "made in China" to "developed in China". Require significant effort and resources. Bartlett and Ghosal (2000) [6] found the cost curve of the pharmaceutical industry to illustrate the evolution of manufacturers from low- to high-performance segments, characterized by technological complexity and profitability, and indicated that such a transition requires complex research and development, and therefore more scientific and human potential. Given the constant increase in technological innovations, the process of overtaking world leaders by Chinese manufacturers requires an increase in the number of networks and 
a more complex organizational structure, goes beyond the national innovation system [7, 8]. This process of follow-up occurs in four stages: (1) pure imitation (2) innovative imitation (3) imitative innovation and (4) endogenous innovation. In this evolution, the government plays a significant role, implementing various policies, passing laws and strategies to cultivate and stimulate domestic drug research and development [9]. As indicated in [10], to speed up the process, China encourages its companies to enter the international market through the acquisition of shares, mergers and acquisitions, leasing, construction of research centers and factories abroad, trying to create an improved institution of supervision and management. The above and other works are mainly a generalization of the approaches used by the Chinese government, ignoring the details of the basic conditions of the program documents, which are aimed at building national potential, and for this they orient Chinese companies to actively use foreign resources.

The aim of the article is to identify the key instruments of state policy in China that determine the scientific, technological and innovative development of the country's pharmaceutical industry.

\section{Materials and methods}

The theoretical and methodological basis for writing the article was scientific concepts and theoretical developments on the development of the pharmaceutical industry; regulations, targeted programs and plans of the Chinese government in science and technology, innovation, finance, investment, taxation, staffing, public procurement, which contributed to the development of the pharmaceutical industry. The study was carried out using the methods of theoretical generalization, comparative analysis and synthesis, which made it possible to identify the key determinants of the development of the high-tech pharmaceutical industry in China.

\section{Research results}

Purposeful and selective industrial policy focused on structural shifts towards high-tech industries, including pharmaceuticals, has been implemented in China since the $1980 \mathrm{~s}$, with the coming to power of Deng Xiaoping [11]. In 1986, the Government launched the State Plan for the Development and Development of High Technologies - Program "863". Biotechnology was identified among its priorities, incl. in the interests of pharmaceuticals. In 1988, they introduced the Guideline Plan for the Development of High-Tech Industries - the Torch Program and began to build zones for the development of high-tech industries in China of both national and regional significance to accelerate the commercialization of scientific achievements of the 863 Program. Today in China there are more than 40 zones for the development of high-tech industry, specializing in the development and development in the production of new drugs [12]. Along with incentives for R\&D and innovation, there are a number of preferences for investors in such zones, including: incentives for the lease of land under industrial facilities, incentives for the payment of income tax and VAT for new companies, financial assistance for the purchase of production equipment and its leasing. There are also incentives to attract professionals and young professionals to businesses and institutions. They are provided with subsidies for the purchase of housing, as well as financial assistance. In addition, pharmaceutical companies located in the zones receive "bonuses" related to infrastructure, in particular, access to electricity, water and other utilities, as well as to the processing and disposal of general waste.

The 863 and Torch programs have laid the foundation for the development of Chinese pharmaceuticals based on advanced technologies. The next step was the State Program for Long-Term and Medium-Term Planning of Science and Technology Development for 2006-2020 [13] (hereinafter referred to as the State Program), which focused further government measures on endogenous innovation. The State Program emphasizes the need for new large projects that should improve the ability of the economy to develop important pharmaceuticals, accelerate the development of their production on an industrial scale, and ensure the development of advanced technologies, machinery and equipment for the production processes of the pharmaceutical industry. In the "Strategies and Measures Are More Important" section of the Program, the strengthening of imports, absorption, assimilation and reinvention of foreign knowledge and experience and the forma- 
tion of endogenous innovations in China are noted. So, the State Program focuses on the further borrowing of foreign know-how, however, not copying Western developments, as was done at the initial stage of the "Chinese revival", but the absorption and adaptation of advanced technologies in order to rethink them for their further development.

The content of Chinese re-innovation is a thorough study of the principles of functioning of a particular object through the use of techniques for reverse engineering and reproduction of research. Ways to obtain foreign technologies can be either completely legal under technology transfer agreements or not entirely, for example, recruiting researchers, industrial espionage or "investment looting" (this term was used by the French Minister of Economy Bruno le Maire [14]). The paper [15] examines China's policy regarding access to Western technologies through mergers and acquisitions and measures by the EU and US leadership related to the protection of their economies and national technological advances from such Chinese investments.

In pursuance of the directives of the State Program, the government introduced a scientific and technological special project "Creation of new important drugs" (hereinafter referred to as a special project) [16], aimed at solving the problems of major diseases, improving the national drug supply system and reducing dependence on foreign technologies and pharmaceutical products. A special project guides researchers to adhere to the "triple" principle of innovative positioning set by the Chinese government - creating new products, meeting important needs and solving key problems of society. In 2019, the guidelines for the implementation of the Special Project were improved by the directive of the line ministry - priority is given to the development of endogenous innovative drugs with new clinical value, generics and biopharmaceuticals that are in dire need of clinical practice, and which have good market prospects. The mechanism of state financial assistance depends on the category of the project:

1) "Basic development of innovative drugs" - a pre-project subsidy from the state in a ratio of at least 1:1. The project applicant must have a clear plan for their own investments and first make a contribution to the R\&D fund of their project;

2) "Internationally approved endogenous innovative drugs" - post-project subsidies.

In 2015, on the recommendation of the Ministry of Industry, the Government approved the Program for the Development of High-Tech Industries "Made in China 2025" [17]. Among its priorities are pharmaceuticals and, in particular, the development of new drugs, as well as the development of the production of machinery and equipment for the modernization of the industry. The program is aimed at endogenous innovation, achieving self-sufficiency and reducing the dependence of the Chinese economy on advanced technology and high-tech goods. For the implementation of this program, the Government of China provided the "Guidelines for planning the development of the pharmaceutical industry" (hereinafter referred to as the Guidelines) [18]. This document clearly reflects the content of the aggressive policy of the Government of China in the interests of accelerating the endogenous innovative development of the national pharmaceutical industry through the use of foreign resources.

The guide calls on all stakeholders: "Take advantage of the country's existing capabilities in the implementation of the Belt and Road Initiative, and make full use of international resources to strengthen technology and attract talent to foster the development of pharmaceutical companies and increase their international competitiveness".

In the context of the implementation of the internationalization strategy, the Management points out the priority "to support enterprises in acquiring or investing in the construction of production bases for chemical raw materials, drugs and traditional Chinese medicines abroad, to promote international cooperation in the use of production facilities and foreign environmental resources, and to expand their presence in local market"; and encourages "mergers and acquisitions and investment in promising properties" to access foreign technology and encourages the international registration of pharmaceuticals, create new sales channels and develop Chinese brands in foreign markets.

To attract foreign capital and technology for the development of the industry, the Guide calls for "encouraging foreign companies to establish research and industrial bases in China for the implementation of contract clinical trials of new drugs and contract manufacturing", as well as to 
expand the production of equipment for the pharmaceutical industry in order to get the opportunity to implement complex solutions.

Separately, the Guidelines indicate the strengthening of mechanisms for financial and tax support for the development of pharmaceuticals, the implementation of which is considered in the context of the State Program and the Special Project. The emphasis is on three instruments: $a$ tax credit for $R \& D$, tax relief for high-tech enterprises, and accelerated depreciation of fixed assets. At the same time, the Management notes the need to develop venture capital funds and equity funds, improve export credit policy and insurance, expand debt financing instruments, and the like. To stimulate demand for pharmaceutical products, it is recommended to improve the public procurement policy in terms of supporting endogenous innovations, as well as in setting standards for assessing the quality of medicines purchased.

In the context of the implementation of the guidelines in 2016, the Government of China clarified the list of high-tech industries for targeted government support [19]. It includes the category "Biotechnology and new pharmaceutical technologies", which covers the following industries: biopharmaceuticals; Chinese medicine, natural medicine; production of chemical medicines; production of new dosage forms and technologies for the preparation of drugs, and the like. Business entities that work in these industries have the opportunity to receive a number of preferences (priority when obtaining permits for office and industrial land, priority to receive assistance from state support funds, participation in large-scale projects supported by the state, receiving subsidies for rent, etc.), but subject to the availability of a certificate of a high-tech enterprise [20]. The main provisions of the approach to the identification of high-tech enterprises in China are analyzed in [11].

To strengthen endogenous innovations, the government of the country in 2018 issued a "Report on an increase in the rate of deduction in the taxation of research and development expenditures", which raised the size of the tax credit for R\&D from 50 to $75 \%$ [21]. Also, to facilitate technological transformations of the economy, the country has improved the policy of accelerated depreciation of fixed assets of enterprises in six industries, of which pharmaceuticals [22]. Accelerated depreciation applies to machinery and equipment used not only in production, but also in R\&D.

Since the technology gap between China and developed countries is still significant, in 2019 the National Development and Reform Commission and the Ministry of Commerce of the PRC presented a new edition of the Catalog of Industries to Encourage Foreign Investment [23], including the pharmaceutical industry, which included 13 areas, including : production of new complex drugs or drugs with active ingredients; production of amino acids, anti-cancer drugs, cardiovascular and cerebrovascular drugs, and the like. Investors who invest in these industries are entitled to preferential treatment for doing business, in particular, tax incentives, simplification of the procedure for considering and approving a project, discounts on land lease, exemption from customs payments. In 2018, the Chinese authorities extended preferences to foreign investors by abolishing the levy of income tax, reinvested in projects in the country (in areas prohibited for foreigners), including those related to the construction of new enterprises.

The population of China is about 1.4 billion people, and then the country's leadership, considers the large domestic market for public procurement as a powerful tool for the development of national pharmaceutical manufacturers. Article 10 of the Chinese Public Procurement Law [24] states: "Public customers must purchase domestic goods, equipment and services, but except for one of the following situations:

1) projects or services that need to be purchased are not available in China or can't be obtained on reasonable commercial terms;

2) purchases are for use outside of China;

3) other laws and regulations provide otherwise. The definition of domestic goods, projects and services is carried out in accordance with the provisions of the State Council. "

The document "Guiding procurement measures for health protection" (article 4) also states: "Public customers should purchase domestic goods" [25]. Although the law does not clearly specify the concept of “domestic goods" (国 货物), in the work "Public procurement in China: the experience of European business that competes for government contracts in China" [26] indicates that such goods are considered, in which at least $50 \%$ of the added value is created on the territory of the 
PRC. According to "smart commercial reasons", these are cases when public customers can purchase foreign products if the domestic equivalent is more than $20 \%$ more expensive than the imported one.

\section{Discussion}

Summing up the above, it is possible to say that the technological breakthrough of China's pharmaceuticals is due to the active policy of the government of the country is to introduce: programs for the development of high-tech sectors, including the program "Made in China 2025", where pharmaceuticals is a priority for which the resources of the state and private sector are directed; tax incentives for $\mathrm{R} \& \mathrm{D}$, accelerated depreciation of fixed assets, reduction of income tax for high-tech enterprises contributed to the modernization and growth of the innovative potential of the industry; support of pharmaceuticals through certification of high-tech enterprises; encouraging foreign investment; provision of preferences in public procurement systems; incentives for the internationalization of production and R\&D to gain access to foreign technologies. Thus, the Chinese government implements a policy of strengthening national potential and its absorption capacity for innovation, as well as large-scale interaction with the external environment as a resource. This thesis is consistent with the theory of Pfeffer and Salanchik (1978) [27] on resource dependence and ways to overcome it, as well as Bert's (1992) [28] concept of interorganizational relations (in formal and informal networks) as a way to build competitive advantage. The most important resources required for the innovative development of pharmaceuticals are knowledge in the field of chemistry, physics, biology, medicine, etc., based on the long-term achievements of scientific schools in developed countries; and also the carriers of this knowledge are people. As Veblen noted, industrial excellence is a body of knowledge obtained from past experience, is contained and transmitted as an indivisible property of the community as a whole [29]. Therefore, attracting foreign resources, the Chinese government is trying to "transfer" this skill and, according to Gerschenkron's concept of the "advantages of backwardness" [30], to accelerate development with a "great spurt".

According to [31], the control of developed countries on the transfer of technologies to China affects the allocation of resources, but can't prevent technological progress and an increase in the competitiveness of the Chinese pharmaceutical industry. At the same time, a number of researchers believe that "Soviet planning can't reproduce Silicon Valley," despite "intrigue, theft of intellectual property rights and the forced transfer of technology by TNCs" [32].

According to [33], China's policy is aimed at obtaining knowledge from foreign companies, at the same time contributing to the formation of China as a partner of global pharmaceutical companies in research and development through contract research organizations that provide outsourcing services for the development of biopharmaceuticals, the implementation of biological analyzes, preclinical and clinical studies and the like. Relatively stable political conditions in China, for foreign investors in China's pharmaceuticals are more important than low labor costs and other factors. A survey conducted by the American Chamber of Commerce in China in March 2020 showed [34] that most companies do not plan to relocate manufacturing operations and change supply chains from China any time soon. In particular, in the short term, more than $70 \%$ of respondents do not plan to move manufacturing and supply operations outside of China through COVID 19. About $40 \%$ of respondents say their long-term supply chain strategy for China will remain the same regardless of the impact of COVID 19.

At the same time, the existing restrictions on access to regulatory documents of China on government assistance in attracting foreign resources and statistics on the transfer of foreign technologies to China, it is impossible to assess their scale and impact on the development of scientific and technological potential of drug production in China based on endogenous innovations. A promising area for further research is the specifics of the Chinese government's policy to attract foreign resources in the context of COVID 19, in particular, new policy documents and their fundamental conditions aimed at the use of foreign resources.

\section{Conclusions}

Thus, the policy of the Chinese government contributed to a change in local factors and the market, intensified the advantages of placement, which led to a change in the strategy of TNCs in 
China from resource-oriented to strategically oriented, aimed at finding new assets to strengthen their own competitive advantages.

At the same time, Chinese companies, following the guidelines of the Pharmaceutical Industry Development Planning Guidelines, continue to pursue an aggressive policy of using the assets of other countries, incl. European, to develop their technologies and innovations in the production of medicines, through direct and portfolio investments, using production facilities and environmental resources. In 2019, the EU leadership approved Regulation 2019/452 "Establishing a framework for the screening of foreign direct investments into the Union Retrieved" [35], according to which biotechnologies, the development of which affects the pharmaceutical industry, are identified as "sensitive" areas, among other things. On October 11, 2020, the rules of the Regulation will enter into force. Many countries have adjusted their existing legislation to filter foreign investment. At the same time, it is possible that China will try to take advantage of the weakening economies caused by the COVID 19 pandemic to expand its presence in the markets of European countries, realizing its programs for the absorption, assimilation and reinvention of foreign knowledge and experience to strengthen the potential of endogenous pharmaceutical innovation in China.

\section{References}

[1] World Economic Outlook Update (2020). A Crisis Like No Other, An Uncertain Recovery. Available at: https://www.imf.org/ en/Publications/WEO/Issues/2020/06/24/WEOUpdateJune2020

[2] Schwarz, P. (2020). European Union to spend half a trillion euros on imperialist interests in coronavirus bailout. World Socialist Web Site. Available at: https://www.wsws.org/en/articles/2020/04/13/euro-a13.html

[3] Science and Engineering (2020). The State of U.S. Available at: https://ncses.nsf.gov/pubs/nsb20201/data

[4] The Indian pharmaceutical industry - the way forward (2019). Mumbai. Available at: https:/www.ipa-india.org/static-files/ pdf/publications/position-papers/2019/ipa-way-forward.pdf

[5] Ni, J., Zhao, J., Ung, C. O. L., Hu, Y., Hu, H., Wang, Y. (2017). Obstacles and opportunities in Chinese pharmaceutical innovation. Globalization and Health, 13 (1). doi: http://doi.org/10.1186/s12992-017-0244-6

[6] Bartlett, C. A., Ghosal, S. (2000). Going global: lessons from late movers. Harvard Business Review, 78 (2), $132-142$.

[7] Hu, H., Zhang, L. (2015). Catch-Up of Chinese Pharmaceutical Firms Facing Technological Complexity. International Journal of Innovation and Technology Management, 12 (4), 1550017. doi: http://doi.org/10.1142/s0219877015500170

[8] Lei, J., Lin, B., Sha, S. (2016). Catching-Up Pattern Among Countries in Science-Based Industries: A Case Study in Pharmaceutical Industry. Journal of Industrial Integration and Management, 1 (1), 1650004. doi: http://doi.org/10.1142/s2424862216500044

[9] Jingxi, D., Yajiong, X., Huigang, L., Rong, S., Yongfa, C. (2011). From Imitation to Innovation: A Study of China’s Drug R\&D and Relevant National Policies. Journal of Technology Management \& Innovation. Santiago, 6 (2), 1-13. doi: http://doi.org/ $10.4067 / \mathrm{s} 0718-27242011000200001$

[10] Zhao, J. (2015). International Market Entry Modes. Advances in Human Resources Management and Organizational Development, 225-253. doi: http://doi.org/10.4018/978-1-4666-7332-8.ch011

[11] Salikhova, O. B. (2012). Vysokotekhnolohichni vyrobnytstva: vid metodolohii otsinky do pidnesennia v Ukraini. Kyiv: NAN Ukrainy, Instytut ekonomiky ta prohnozuvannia, 624.

[12] National High Technology Zone. Available at: http://www.most.gov.cn/gxjscykfq/index.htm

[13] Plan of the National Medium and Long-term Plan for the Development of Science and Technology (2006-2020). Available at: https://www.itu.int/en/ITU-D/Cybersecurity/Documents/National_Strategies_Repository/China_2006.pdf

[14] Le Maire fustige «le pillage de technologies» chinois et refuse des investissements (2018). Available at: https://www.challenges.fr/economie/le-maire-fustige-le-pillage-de-technologies-chinois-et-refuse-des-investissements_558913

[15] Salikhova, E. (2020). Turbonyani. LB.ua. Available at: https://lb.ua/economics/2020/02/25/450866_turbonyani.html

[16] A new special drug project accompanies people's health. Available at: http://www.gov.cn/zhengce/2018-10/10/content_5329091. htm

[17] State Council Press and Distribution Report "Made in China in 2025”. Available at: http://www.china.com.cn/legal/2015-05/19/ content_35606051.htm

[18] Notice from the six print and distribution departments of the Pharmaceutical Industry Development Planning Guide. Available at: http://www.gov.cn/xinwen/2016-11/09/content_5130391.htm

[19] State-supported high-tech industries. Available at: http://www.waizi.org.cn/law/6441.html

[20] 2016 National High-tech Enterprise Certification Management Measures (latest version). Available at: http://www. gaoxinbutie.com/faq/480.html 
[21] Ministry of Finance, General Directorate of Taxation, Ministry of Science and Technology, Notification of an increase in the pre-tax deduction rate before taxes on research and development costs Tsai Shui (2018). No. 99. Available at: http://www. chinatax.gov.cn/n810341/n810755/c3754895/content.html

[22] An announcement by the State Tax Administration on current tax policy issues regarding accelerated depreciation of fixed assets. Announcement No. 64 (2014). Available at: http://www.chinaacc.com/zyssfg/hu2014111718511263263436.shtml

[23] Catalogue of Industries for Encouraging Foreign Investment (2019). Available at: https://www.pkulaw.com/en_law/2e6fab85 49042788bdfb.html

[24] Government Procurement Law of the People's Republic of China (2014). Available at: http://fgw.yinchuan.gov.cn/fgzc/ flfg/201812/t20181221_1224321.htm

[25] Notice to the National Health Commission on the press and distribution of interim public procurement management measures. Guowei Caifafa (2018). No. 17. Available at: http://www.waizi.org.cn/doc/38884.html

[26] Public Procurement in China: European Business Experiences Competing for Public Contracts in China (2011). Public Procurement Study. European Chamber. Available at: https://cbi.typepad.com/files/euccc-public-procurement-in-china-april-2011.pdf

[27] Pfeffer, J., Salancik, G. R. (1978). The External Control of Organizations: A Resource Dependence Perspective. University of Illinois at Urbana-Champaign's Academy for Entrepreneurial Leadership Historical Research Reference in Entrepreneurship. Available at: https://ssrn.com/abstract=1496213

[28] Burt, R. S. (1992). Structural Holes: The Social Structure of Competition. University of Illinois at Urbana-Champaign's Academy for Entrepreneurial Leadership Historical Research Reference in Entrepreneurship. Available at: https://ssrn.com/ abstract $=1496205$

[29] Veblen, T. (1921). The Engineers \& the Price System. New York: B. W. Huebsch, inc., 169.

[30] Gerschenkron, A. (1962). Economic Backwardness in Historical Perspective. The Belknap Press of Harvard University, 456.

[31] Hui, J. (2017). American export control, technology spillover and innovation of Chinese pharmaceutical Industry. Pakistan Journal of Pharmaceutical Sciences, 30 (3), 1151-1155. Available at: https://pubmed.ncbi.nlm.nih.gov/28671099/

[32] McGregor, J. (2010). China's Drive for 'Indigenous Innovation': A Web of Industrial Policies. US Chamber of Commerce. Available at: https://www.uschamber.com/sites/default/files/documents/files/100728chinareport_0_0.pdf

[33] Schweitzer, S. O., Lu Zhong, J. (2018). Pharmaceutical Economics and Policy: Perspectives, Promises, and Problems. Oxford University Press, 408. doi: http://doi.org/10.1093/oso/9780190623784.001.0001

[34] A Joint Survey: Supply Chain Strategies Under the Impact of COVID-19 of Large American Companies Operating in China (2020). Available at: https://www.amcham-shanghai.org/en/article/joint-survey-supply-chain-strategies-underimpact-covid-19-large-american-companies

[35] Regulation (EU) 2019/452 of the European Parliament and of the Council of 19 March 2019 establishing a framework for the screening of foreign direct investments into the Union. Available at: https://eur-lex.europa.eu/eli/reg/2019/452/oj?locale=en 